\title{
Karate's ambiguity: Traditional martial art or modern combat sport
}

\author{
Rudolf JAKHEL* \\ Faculty of Sport, University in Ljubljana (Slovenia)
}

8th IMACSSS International Conference Abstracts, Viseu (Portugal), October 10-12, 2019

Type: Oral communication

\begin{abstract}
After a radical conversion of the old Okinawan, anti-samurai martial art toti in the 1920s, a new, in effect Japanese modern combat sport, karate, came into being. The very first karate sports contest already took place in 1930. But, at the end of 1950s, karate started to be exported to the Western world as a traditional martial art of Japanese samurai, even if the samurai had not known karate. That then already omnipresent doctrine has allowed no other perception despite the fact that, globally, the prevalent phenomenon in the field has been karate sports contests in bouts and katas. Exposing the concept of karate as a traditional martial art to be an unhistoric, artificial ideological superstructure, this study is based on more than 50 years of accumulated scepticism of the author that has been confirmed through communication with students of various karate styles and the evaluation of several publications and studies. It is hoped that the findings of this basic study will encourage the sports scientific community to favor further research directed to indisputable and unambiguous explanation of karate.
\end{abstract}

Keywords: Martial arts; combat sports; traditional karate; toti; gendai; budo; bouts contests; kata contests.

\section{Introduction}

Through regular communication with students of various karate styles, the author has found out that a great number of them agree with his doubts about karate, but avoid to talk about that publicly. In such an atmosphere, the declared concept of karate as traditional martial art can, of course, keep defining karate despite of the ever growing prevalence of karate sports contests. Thus, it is much needed to analyze this ambiguity.

\section{Objectives}

The sense of this research has been to reveal - so far possible by undemanding methods of critical and reflective reasoning and deduction - and expose various contradictions and origins of the prevailing images, beliefs, and postulates in karate. It shall provoke and stimulate further, more profound historic socio-cultural research of this theme.

\section{Methodology}

The reasearch was conducted by evaluating selected publications of some leading Japanese authors (translated into English and German), as well some articles, studies, and the extensively analytical opus of the German "Budo Studien Kreis" (lead by Werner Lind, see the references section). The base and measures for the evaluation has been author's scepticism accumulated in over 50 years of various activities in karate - with manifold karate experience, from top contestant to international coach and judge, publicist, researcher, and lecturer. The subject of study was (a) the inconsistencies in karate's historic explanations and justifications of its appearance, social role, didactic goals, training contents and methods, etc., as well as (b) the contradictions - and their sources - between the karate's declared mission and doctrine as a traditional martial art, and its rather differing phenomenon in the field, i.e. as an omnipresent combat sport. 


\section{Results}

The following statements summarize some main inconsistencies and contradictions of the nowadays karate, without claiming to be exhaustive or definitely ordered yet.

1) The Japanese karate (as "empty hand") started in 1920s with radical sportification and Japanisation of its martial art predecessor, Okinawan toti or todi (tote or tode in Japanese). The conversion was total: there are differences in at least 20 aspects of the two disciplines. The most indicative one is the deliberate change of the meaning of toti's late name karate (at the end of $19^{\text {th }}$ c.) from Chinese hand to empty hand. Already in 1930s, there were held sporting contests in karate and to that end also special sparrings, kumite, were introduced. Some prominent karate masters themselves (e.g. Nakayama) used the name sports karate. All that indicates that karate (empty hand) has been de facto established as a modern Japanese combat sport, but nevertheless keeps declaring to be a traditional Japanese martial art.

2) The main four karate styles (empty hand) were in 1936 recognized by the then imperial agency Butokukai as an original Japanese gendai budo discipline karatedo. The other gendai budo disciplines like judo, kendo etc. emanate from their ancient (before abolishment of the samurai 1868) koryu bushido disciplines like jujutsu, kenjustu,etc. But there is no koryu budshido karatejutsu. Chronologically, samurai could not even know karatedo (empty hand), and its predecessor karate alias toti (Chinese hand) they had experienced only as its targets and victims.

3) The gendai budo disciplines have been politically furthered as combat sports to be practiced by general population. But these new sports also kept bounds to martial techniques and martial spirit of the samurai. This has been claimed to apply also to the new Japanese combat sport, karatedo, even if it had no connection with samurai martial arts. Hence, this claim is an unhistorical, artificial construction.

4) The Japanese karate (empty hand) was in the eyes of their founding fathers the modern karate, while its predecessor, the Okinawan karate (Chinese hand), named originally toti, was considered as the traditional karate. However, toti has been established in 17th c. deliberately as a specific, secretly practiced anti-Japanese, anti-samurai deadly martial art of the then by the Satsuma clan occupied and oppressed Okinawans. So, if toti shall be the traditional karate, then the Japanese karate (empty hand) is based on toti's anti-Japanese tradition.

The central place in karate as a traditional martial art is considered to belong to kata due to (a) its real fighting techniques and (b) its spiritual (zen) contents. But there can be found much of ambiguity.

5) The modern karate katas are based on Okinawan toti katas and these are derived from some Chinese katas (dao). Thus, in the last consequence the Japanese karate katas continue the Chinese martial arts tradition. The change of the meaning of karate from Chinese hand to empty hand cannot suppress this logical conclusion.

6) Out of the 24 toti katas, taken over by the Japanese karate styles, have emerged much over 100 karate katas, 96 of which are approved by the WKF. Hence, the great majority of karate katas is modern, composed by masters of various karate styles and as such far from any martial art tradition.

7) There are also sports contests in karate katas. The criteria for rating are the motor perfection and aesthetics instead of the real fighting efficiency (as in toti katas) and the spiritual contents (as in Chinese daos and a few late Okinawan katas). Karate kata has thus become a particular kind of karate sport beside karate sports bouts.

8) In the Okinawan toti, katas were the main form of training. The aim was neither the motor perfection nor any spiritual gain, only the efficiency of the deadly strike kime (chimei). By toti kata training the Okinawan freedom fighters perfected the deadly skill needed in attacks on fully armed samurai. Contrary to that, training of karate kata does not prepare neither for real martial fight nor for contest in sporting bouts. Nevertheless, all contesting karate styles persist 
on kata training as the basic preparation for sports bouts. This claim ignores the experience of karate contestants (confirmed by students of various karate styles) that good kata perfomers are not (necessarily) also good fighters, or the other way around.

\section{Discussion and Conclusion}

These rational observations will probably be shocking and thus rejected by eager adherents of (all?) karate styles, but hopefully not also by researchers bound to "sine ira et studio". After around 60 years of karate as global sport - and soon 90 years since the first karate sports contest it is time for the sports academic community to look critically into the ideological - even mythical structure of karate and its origins. The clarification of prevailing confusions and ambiguities should initiate their elimination and thus facilitate further sporting development of karate.

\section{References}

Cynarsky, W.J. (2014). The European karate today: The opinion of experts. Ido movement for culture. Journal of martial arts anthropology, 14(3), 10-21. doi: 10.14589/ido.14.3.2

Funakoshi, G. (1975). Karate-do My Way of Life. Tokyo, New York, San Francisco: Kodansha America.

Haines, B. A. (1968). Karate's History and Traditions. Tokyo: Rutland.

Jakhel, R. (1998). Modern Sports Karate. Basics of Technique and Tactics. Aachen: Meyer\&Meyer Verlag.

Jakhel, R. (2017-18). Borilni športi - 2. del: Karate in sorodne discipline. Kompendij predavanj [Combat sports - Vol. 2: Karate and related disciplines. Compendium of lectures]. Ljubljana: Faculty of Sport.

Jakhel, R., \& Pieter, W. (2013). Changes in participation motives in karate 1970-1999. Ido movement for culture. Journal of martial arts anthropology, 13(1), 48-57. doi: 10.14589/ido.13.1.7

Kanazawa, H. (2011). Kumite shotokan karate. Masberg: Plaidt.

Lind, W. (1995a). Budo - Der geistige Weg der Kampfkünste. O.W. Barth Verlag: Bern, München, Wien.

Lind, W. (1995b). Die klassische Kata - Der geistige Herkunft und Praxis des traditionellen Karate. O.W. Barth Verlag: Bern, München, Wien.

Lind, W. (1997). Okinawa Karate - Geschichte und Tradition der Stille. SVB Sportverlag: Berlin.

Lind, W. (1999). Das Lexikon der Kampfkünste. SVB Sportverlag: Berlin.

Nakayama, M. (1978). Best karate: Kumite 1. Tokyo: Kodansha International.

Swenen, F. (2009). The Evolution of Karate: From Secret Martial Art to Worldwide Cultural Sport. Retrieved from http://sfdojo.be/wp-content/uploads/2014/05/ThesisBudai.pdf 